\section{ECONOMICS}

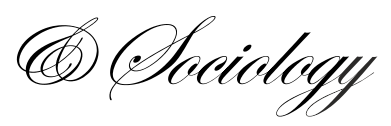

\author{
Neringa Barakauskaitè- \\ Jakubauskienè \\ Department of Business Economics \\ and Management \\ Kaunas Faculty of Humanities \\ Vilnius University, Lithuania \\ neringabj@gmail.com
}

Received: March, 2011

1st Revision: May, 2011

Accepted: July, 2011
Neringa Barakauskaitè-Jakubauskienė, Logistic Capital Management Theories and Theoretical Aspects of Economic Growth Cycle, Economics \& Sociology, Vol. 4, No 1, 2011, pp. 33-45.

\title{
LOGISTIC CAPITAL MANAGEMENT THEORIES AND THEORETICAL ASPECTS OF ECONOMIC GROWTH CYCLE
}

\begin{abstract}
One of the most important characteristics of the economy is cyclicality - a periodic, regular short and long-term economic fluctuations. Cycle of economic growth - the sequential rise and fall variations of the main macroeconomic indicators, conditioned in appreciable activity changes in many types of economic activities. In the economic theory there are distinguished four stages of the economic growth cycle, passing one after the other - the peak, recession, crisis and boom differ from one another in the length of time, intensity, various macro-economic factors' impact to the economy and therefore never alike and regularly recurring. One of the newest approaches in economic growth theory, which deals with the limitations of economic growth and its causes - the logistic capital management theory created by Prof. S. Girdzijauskas (2006), which is based on the capital niche's, as the capital's growth space, concept of finality. The authors of the theory applied the definition of the classical ,bubble" to the growth cycle and confirmed that in the cyclical economical fluctuations in some cases, forms a bubble effect whereas applying and introducing to it a fundamentally based output rate it is obtained an economic bubble phenomenon. The article deals with the theoretical aspects of logistic capital theory and the economic growth cycle. Purpose of the article - to review and compare the theoretical aspects and relationship between the logistic capital management theory and the economic growth cycle. Logistic capital management theory - is one of the newest approaches in the context of the economic activity's cyclical phenomena. In practice, this theory and suggested marginal capital growth models are not used for examining the economic growth cycle and the economic dynamics processes, an important point is that the logistic capital management theory and the new viewpoint of the authors - limited capital growth, clearly demonstrates that the capital as the country's GNP growth cannot be infinite and sooner or later it ends.
\end{abstract}

JEL Classification: D53, E32

Keywords: financial markets, economic/business cycles, business fluctuations, logistic capital, bubble theory. 


\section{Introduction}

Economic growth can be defined as an increase of country's production capacity, the long-term country's productive potential development, which is expressed by the increase of the national product volume; economic growth and development - a process, evidenced by the gross domestic product (GDP) volume fluctuations within a certain period of time, generally indicates changes in countrys's economic performance results (TF Cooley and EC Prescott, 1995). Economic growth theories generally refer to the growth of potential output, influenced by the growth in demand or observed consumption. In modern economic theory growth is largely based on and related to the investment (Blanchard, 2007).

One of the newest approaches in economic growth theory, which deals with the limitations of economic growth and its causes - professor Girdzijauskas (2006) designed and developed logistical capital management theory, which is based on the niche of the capital, as the capital growth area's finality concept. Author examinating the limitations of the capital (market) niche in his works has revealed an economic phenomenon - ,price bubble“, he examined the causes and factors affecting it's formation and found that in the effect of market niche arising paradoxes such as ,the credit trap“ and ,increasing profitability“ - are the main reasons of a number of economic and financial crisis. By studying the processes of economic growth and the causes of the formation of economic bubbles in cyclical fluctuations professor S. Girdzijauskas and prof. D. Štreimikienè $(2008,2009)$ applied classic „bubble“ definition to the economical growth cycle and confirmed that during the cyclical fluctuations in some cases, forms the bubble effect and applying and introducing to it a fundamentally based output rate - economic bubble phenomenon is obtained.

The purpose of the article is to review and compare the theoretical aspects and relationship between the logistic capital management theory and economic growth cycle.

Research objectives are formulated as follows:

- to review the viewpoints of those concerned authors who analysed economic growth cycle theories and the phases of economic cycle entailing the change processes in economic dynamics;

- to analyze the logistic capital growth model and economic bubble formation mechanism;

- to deliver the logistic capital management theory's application opportunities in an aspect of economic growth cycle.

The article executes a survey analysis, system analysis and synthesis of the Lithuanian and foreign authors' scientific literature sources. In practice, the logistic capital management theory and suggested marginal capital growth models are not used while examining the economic growth cycle and economic dynamics processes, but it should be noted that the logistic capital management theory and the new viewpoint of the authors that capital growth is limited - apparently shows that the capital as well as the country's GNP growth can not be infinite, because of their growth limitations.

\section{Classic economic growth cycles}

Economy is characterized by persistent short-term and long-term cyclical fluctuations. The first scientists who drew attention to the cyclic phenomena in the economy and begun to explore them - L. S. Sismondi (1839), T. Maltus (1820). Cyclical nature as a random and short-term phenomenon in his works was treated by A. Smith (1776), J. B. Say (1803), D. Ricardo (1923), G.S. Mils (1848), A. Marshal (1900) (Čiegis, 2002). Many economists attribute economic cycles' (oscillations) theory together with the theory of economic growth to the topic of macro-economic dynamics. According to the scientific 
literature - the economic cycle theory emerged and began to evolve, while searching for answers to the question of why in the economy happen the economic fluctuations? Because of the complexity of the problem the economic science has not provided any answers to this question (Blanchard, 2007). Economic growth cycles demonstrate the complex image of the processes happening in economic dynamics in reality.

In the theory of economy mainly the variations in industrial economic activity are studied in accordance with C. Juglar (1860) cycles, cycles caused by interest rates and price fluctuations. J. Kitchin (1923) industrial reserve cycles are screwing the great cycles of the economy (Besomi, 2005). S. S. Kuznec 1971 received the Nobel Prize in Economics for empirically based interpretation of the economic growth, which led to the new and advanced economic development and social structure's development process. He noted that the cyclical nature is very affected by the growth and development of new industry. N. D. Kondratjev (1926) hypothesized that the industrial development is cyclic (Фомина, 2005). Schumpeter endorsed this concept, calling the „long waves” $-N$. Kondratjev cycle - historical waves, and in 1936 presented a new interpretation of economic development, stressing the importance of innovations in order to avoid fluctuations in the economy, i.e. that fluctuations in economic activity will be avoided if the innovative processes will take continuous nature, progress innovations increase business opportunities in the market, producing competitive products. The basic idea of J. Schumpeter theory is associated with economic fluctuations - that the entrepreneurs with their own capabilities and initiative can create entirely new opportunities for investment in economic growth and employment. The decisive factor and an innovator, leading to the rapid growth is the profit derived from the innovations provided to the market. N. Kondratjev and J.Schumpeter theory was further developed by the economist Ch. Freedman (1963) who emphasized the need to take into account fluctuations of the real GDP in the ratio with potential GDP and the process of technological progress.

The classic primary definition of the economic cycle, stated by K. Mitchell in 1946, the economic cycles include economic change over particular time between the relatively rapid growth of economic output (boom) and the relative stagnation (fall) periods. A. F Burns and W. C Mitchell in the book „Business Cycle Measurement“ (1946) presented the classic definition of the economic cycle: ,the economic cycle is a type of fluctuation found in the general economic activity of nations that organize their work mainly at business enterprises: a cycle consists of expansion stages occurring at about the same time in many economic spheres, after some time in the economy there also take place the overall recession, economic contraction and rebirth, which merge into the next phase of the development cycle".

Macro-economic dimensions - production, income and employment fluctuations in the economy happen regularly, according to Moore G. H. (1983) environmental changes affect economic activity, the economy is characterized by constant pursuit of equilibrium, which may at any time be prevented by the dynamism and volatility of economic activity. Further there are briefly overviewed main characteristics of the cycle phases, which show the fluctuations of economic growth dynamics and change processes.

The crisis is the lowest point in the cycle of economic growth. During this period, unemployment rises and aggregate demand falls. Corporate earnings and profits decline, incentives for new investments are low, international trade fails. If such a fall in the economic cycle stays a longer period the time it is considered the beginning of a global depression (Elster, 1983). Table 1 presents the theories explaining economic crises. 
Table 1. Theories explaining the economic crises

\begin{tabular}{ll}
\hline \multicolumn{1}{c}{ School } & \multicolumn{1}{c}{ Explanation of crises causes } \\
\hline Classical & $\begin{array}{l}\text { Presenting the unsuccessful person's, the government's behavior's randomness, as } \\
\text { the reason for the infringement of the natural regulation mechanism of economy. } \\
\text { School findings are based on a static conception of economic equilibrium, without } \\
\text { analysing the dynamics of economic development. }\end{array}$ \\
\hline Neoliberal & $\begin{array}{l}\text { Combines the theories based on the dynamic analysis of economic life. These } \\
\text { theories combine the development of economic crisis with objectively existing } \\
\text { factors, violating the economic equilibrium. Trying to find those factors were } \\
\text { created various anti-cyclical policy strategies, justified government intervention to } \\
\text { the economy. }\end{array}$ \\
\hline Marxist & $\begin{array}{l}\text { German philosopher K. Marx (1818-1883) contrasting the pre-capitalistic crisis, } \\
\text { caused by lack of production, and capitalistic crisis, caused by the overproduction } \\
\text { of goods. In one case the cause of the crisis was seen as a gap between an } \\
\text { objective evolution of production means and an adequate capital accumulation, in } \\
\text { the other case - as the market demand specified by the incorrect distribution of } \\
\text { revenue and the distortion of an average profit rate movement. }\end{array}$ \\
\hline
\end{tabular}

Source: compiled by the author, based on Тамбовцев (2009), Štreimikienè, D., Ramanauskiene, J. (2005), Elster (1983).

The main causes of crises according to S. Girdzijauskas (12/03/2009) are described by the two currently unrecognized economic paradoxes: I. The increasing profitability paradoxinvesting capital in a closed economy (market), while the investment environment declines, the profitability of invested capital increases. II. Paradox of credit traps - development of the loaned capital, surpassing own capital, as a result of the shrinkage of the capital niche. Logistic model shows that the dynamics of the loaned capital is much faster than own capital's. In the dynamics of economic growth in the respect of time economic crises and financial shocks are regarded as indispensable satellites of economic growth cycle without them the economic growth and forward movement would be impossible. State regulations allow to mitigate the outcomes of crises and suffered losses, but do not go completely, because the modern crises assume new forms and display in the new economic sectors, states Портной (2000).

Economic recovery (off) period is defined - in this stage of the cycle, the economy begins to emerge all the signs of recovery. An important role falls to private investments. Private investments are encouraged by the reduced during the recession interest rate and low market price of investment goods. As stated Тамбовцев В. (2009) "international trade stabilizes the economic situation - the reduction in prices increases export opportunities, innovative activities are stimulated, analogically import is decreasing“. On the other hand, one can add the fact that innovations coming to the market and technological advances further accelerate the economic good times, paving behind themselves the self-rising consumption and prices, rising inflation trail.

Apex (expansion, boom, break) - in this period of cycle there forms tension in the labor market, may appear shortage of skilled manpower, emerge the deficit symptoms in materials and supplies market, increasing output requires bigger investments, resulting in a growing investment costs, that increase the demand for free money. „Increased demand leads to price increase, this may lead to product shortage in the market, rising prices and rising wages incite increasing commodity prices and production outlay. Economic activity of the country is becoming profitable“" (Navickas Bagdonaite, Jusčius, 2006). 


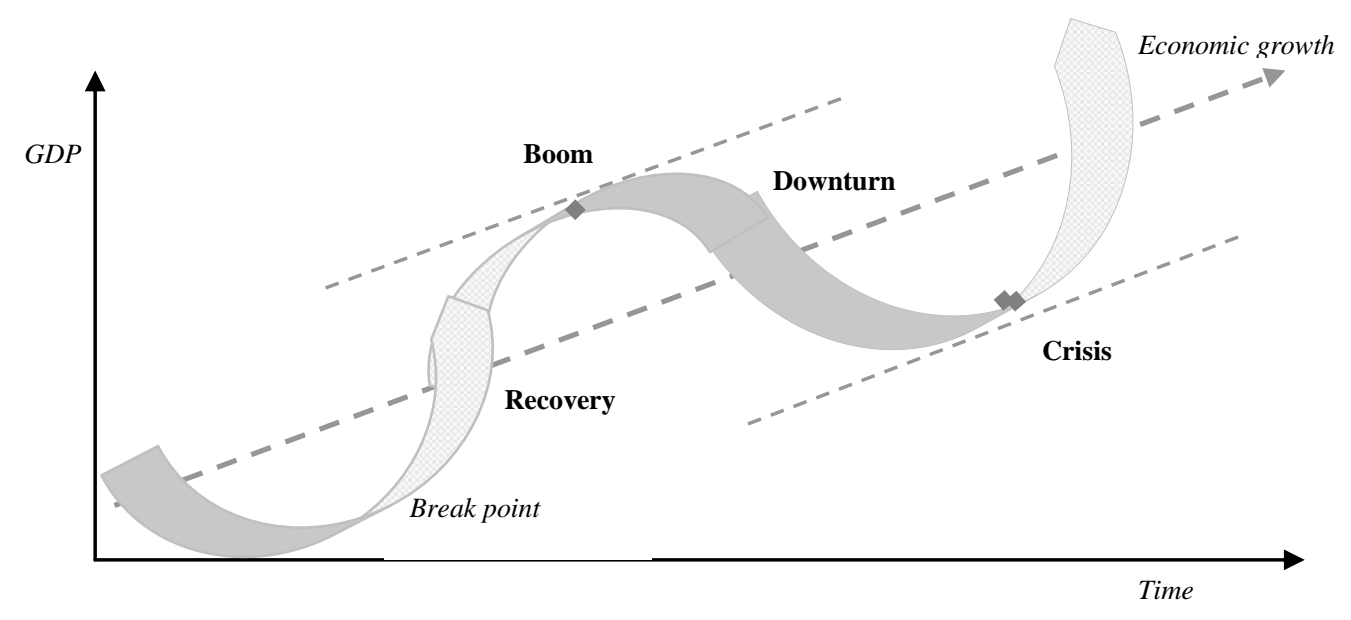

Figure 1. The economic growth cycle phases

Source: author's presentation.

The economic downturn - recessional period of time, when economic activity begins to decline. The decline stage of general output, employment and sales is characterized by impairment in many sectors of the economy. Тамбовцев B. (2009) states that „the loss of the need for new investments reduces the desire to install new equipment". At the time of recession, sharply reduces investment demand, long comsumption products' purchase, whereas short consumption products' output and demand stays unchanged. Downturn ends in the break or turning point where economic activity is lowest.

Macro-economic literature states that in the short and medium term, economic fluctuations dominate in the economy and in the long term - economic growth. Economic cycle fluctuations may be very different and influenced by a variety of reasons. The process of formation of cycles in the literature is often based on increased demand, technological progress and innovations. However, it is important to note that when the economy is saturated and emerges excess demand, which leads to the growth of inflation rate and overproduction, a cycle of economic boom forms and behind it goes the next critical stage that relates to the country's economy's external sector disbalances and an increasing credit portfolio growth rate. On the other hand the economic factors' influence to the economic growth largely depends on the involved in economics behaviour, reactions and interests (high-profit pursuit), external environmental factors, the measures of economic policy application. Thus, in one case, the cycle may not be intact to the holding of goods and services, market segments or economic sectors, in another case it affects individual and also economies of countries together and creates a chain sequence of causes and effects.

\section{Logistic capital growth}

In theory capital growth forms are considered to be a rectilinear proportional growth and exponential capital (model of compound percentage) growth, which is appropriate only when the growth of capital isn't bound to external factors and when capital growth is limited by external factors, such changes in capital are called marginal or logistical. Both of these capital growth forms are considered as an infinite growth, but what grows, must converge, in other words, growth needs to have an end and be able to approach the limit. Here it is used the term logistics, which is associated with any population's limited growth. With the help of the law of logistics an economic growth can also be described, one of which growth restrictive 
factors is - capital (Girdzijauskas, 2006).

The first scientist, who tried to adapt the law of logistic to the biological population's growth assessment, was P. V. Verhulst (1804-1849), later O. C Fereira (1998) has used this law for exploring Brazil's economic growth and confirmed that the logistic growth model better than an exponential allows to evaluate the growth. Prof. S. Girdzijauskas (2006) pointed out that these models have the disadvantage - the used growth function is not expressed with the compound percentage, therefore further Professor's works developed to the new Logistic capital management theory.

As a representative logistic growth model in theory is accentuated P. Verhulst (1847) model of population growth, where growth limitation is estimated by the multiplier reflecting a level of the completion of the certain system (Girdzijauskas, Streimikiene, Mackevicius, 2009/2):

$$
\left[1-\frac{K}{K_{m}}\right]
$$

where:

$K_{m}$ - the maximum marginal biological population's value (expressed y the units evaluating the quantity of product);

$K$ - existing value of the same population's product.

This ratio shows the percentage part of the population's filling, and the multiplier the free part of the population that can be filled. These markings are used also in the logistic capital management theory, while examining the capital growth consistent pattern.

$$
\frac{d K}{d t}=\left(1-\frac{K}{K_{m}}\right) \cdot \ln r \cdot K
$$

where:

$K$ - future capital value (real capital) at time t, where $\mathrm{t} \geq 0$;

$K_{m}$ - the maximum (marginal) capital value (potential capital);

$\ln r$-growth rate evaluative factor, in addition the proportionality factor $\mathrm{k}$ is taken equal to the natural logarithm of the number of some $r(r>0, r \neq 1), k=\ln r$.

Applying the logistic model to the analysis of the economic system and adjusting a similar growth limiting multiplier and the other rates to the differential equation of capital variation, it is obtained a Logistic capital growth function (Girdzijauskas, 2006).

$$
K=\frac{K_{m} \cdot K_{0} \cdot(1+i)^{t}}{K_{m}+K_{0}\left((1+i)^{t}-1\right)}
$$

where:

$K_{0}$ - the original capital value;

$K_{m}$ - the maximum (marginal) value of capital;

$i$-interest rate;

$t$ - the time of collection. 
Dividing the equation's right side numerator and denominator by the ratio of $\mathrm{K}_{\mathrm{m}}$ and indicating the ratio $\left(\frac{K_{0}}{K_{m}}\right)$ with a letter

$$
S_{0}\left(\frac{K_{0}}{K_{m}}=S_{0}, 0 \leq S_{0} \leq 1\right)
$$

we obtain the so-called saturation coefficient. This coefficient is very important in theory while examining the capital growth consistent patterns (Girdzijauskas, SA, 2006). $\mathrm{K}_{\mathrm{m}}$ is very high. Thus capital can not grow at the even pace and for a long period of time. Usually in the theory and practice capital growth is calculated by compound interest model. However, this can be done as long as capital growth isn't bound to external factors (Girdzijauskas, Štreimikienè, 2008/1).

Capital growth rate is determined by the compound interest model, when capital resources are endless. This rate as the future capital value is rising exponential function. This means that as long as the capital growth isn't restricted by resources - capital growth rate increases. After executing mathematical transformations the expression of capital growth rate

$$
\left(\frac{d K}{d t}\right) \text { is obtained: } \frac{d K}{d t}=K_{0} \ln r\left(\frac{r^{t}}{1+S_{0}\left(r^{t}-1\right)}-\left(\frac{r^{t}}{1+S_{0}\left(r^{t}-1\right)}\right)^{2} S_{0}\right)
$$

where:

$K_{0}-$ the initial amount of capital;

$S_{0}$ - the initial saturation factor;

$\ln r$ - growth rate evaluative factor.

Here formula (4) shows that the capital growth rate is variable. Initially, the growth rate increases, but as it reaches to the maximum starts to decline and over time gets close to a zero. The obtained capital growth rate decrease is important not only theoretically but also practically. The rapid capital growth at the beginning of investment is no guarantee of investment efficiency, even with limited resources will remain constant (Girdzijauskas, Streimikienè and others, 2009). Thus, following the principle of logistic law an economic growth may be described, and it's one of the factors limiting the growth is capital.

In practice, these processes of capital growth rate (capital investment growth rate increases) proceed until the economy is not affected by scarce resources, in other words, until then, when the markets have room to grow, but when there appear more market players, competition increases, and functions other factors of economic equilibrium, there forms the saturation effect of economic sector or branch and in this case the capital growth rate starts to suddenly slow down and significantly affects the economic areas in which investments were most effective at the beginning of the investment. In such a situation, the solution to the problem may be only scientific, technological and innovation progress, allowing the creation of new markets and stimulation of economic growth cycle development processes.

\section{The economic growth cycle in the aspect of the logistic capital management theory}

Economic instability in the literature is defined as a permanent state of the economy, therefore economic indicator's - the gross national product's - extent is steadily fluctuating, in the long term, it is expressed as the NP growth, and in the short - the NP may increase or 
decrease. Cyclical economical fluctuations from crisis to the peak stage and the economic „bubble“ formation causes are not still adequately tested and remains as a clear challenge to the economic theory. Logistic capital management theory developed by Professor S. Girdzijauskas (2006) describes the economic growth limits and reasons causing the economic „bubbles"“ (booms') formation, this is the new approach explaining the economic „burbles" formation.

The definition of a bubble says that the bubble - a very significant increase in property prices, when the price is very well above the fundamental property value (Garber, 1990). Bubble formation size depends on market expectations, which may affect consumption, investments and improve labor productivity. Considered the principal cause conditioning the emergence of the price „bubbles“ to be a weak financial system and excessive currency liquidity (Martin, Ventura, 2010). When interest rates are not high, investors are reluctant to keep their capital in savings accounts. In order to increase their capital they are borrowing from banks and investing in stocks or real estate. Blanchard O. (2007) argues that the rational and professional investors operating in the market may be capable of forming a „bubble“. V. Moskaliova (2009) states that the emergence of bubbles is characterized by two conditions - fundamental and psychological. The first condition is related to the exhaustion of the growth space, and the second condition - to the desire to earn and get profit. Bubble formation passes two stages: first (fundamental) when the market because of the growth resources collapse begins to increase capital return (gives a signal to market participants about increasing profitability), second (psychological) - when there is willingness to invest profitably and earn well. The first condition ensures bubble emergence, the second condition determines its size.

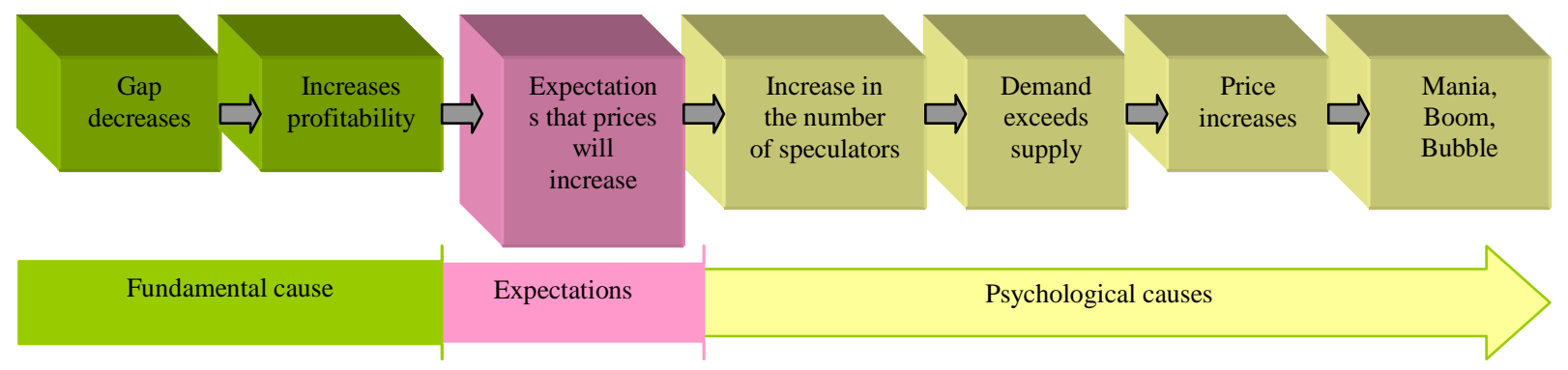

Figure 2. A sequence of the bubble formation causes and factors

Source: Moskaliova V. (2009)

According to S. Girdzijauskas D. Štreimikienè and R. Mackevicius (2009) applying the definition of „bubble“ to the economic cycles, the definition of the economic bubble could be formulated as follows: ,the country's (regional) economic bubble - is a situation when it is recorded a very significant economic growth, when the economic value (the value of GDP) far exceeds the fundamentally based production volume". Here the authors offer to evaluate the fundamentally based country's production volume through the impact of loaned capital and the impact of the different market sectors on overall GDP growth, focusing in particular on the construction and market area value serving it. In other words, when economic growth is based on the loaned capital, and if the level of real GDP is distorted by price bubbles formed in many economic sectors (construction sector and real estate market), the authors state, that then one can signal, that the overheating of the economy is coming and the sudden descent and following it - the economic crisis, i.e. processes, which the authors equate with the formation of the economic bubble and the expected explosion. 
The concept of the capital and it's characterization occupy an important place in the theory. Inherent feature of capital - growth, similarly grow the GDP (GNP), but the growth needs space, cyclical economic development confirms that the economic growth is limited. As state S. Girdzijauskas and D. Streimikiene (2009), the country's economic capital - a key driver of economic growth: „Analyzing the growth of the capital it is defined that there is a certain threshold of potential capital (capacity). Invested capital is only a fraction of the existing capacity, this part of the capasity - known as the real capital. The residual capacity of the investment is devoted to the capital growth and is defined as a capital niche“".

The real capital in the case of economic cycle corresponds to the active (created), the real GDP in the economy. The residual part of the investment capacity is devoted to the capital growth and is defined as a capital niche, similarly we can define it (relative value) as GDP (GNP) niche.

Potential capital - is related to the investment environment, which depends on the economic conjuncture. Sometimes it is called supporting (transporting) the investment capacity of the country (Girdzijauskas, Štreimikienè, Mackevicius, 2009).

Potential capital (Fig. 3) can be expressed by the formula (6):

$$
K_{p}=K_{r}+K_{g}
$$

where:

$K_{p}$ - the potential capital;

$K_{r}$ - the real capital;

$K g(G A P)$ - a capital gap (the difference).

According to the equivalent of the niche of GDP (gap), the capital difference can be expressed by the formula (6):

$$
K_{g}=1-\frac{K_{r}}{K_{p}}=\frac{K_{p}-K_{r}}{K_{p}}
$$

where:

$K_{p}$ - potential capital, the largest productive capital that can be productively invested in the current economic situation (usually equal to 1 );

$K r-$ the real invested capital, present in a potential capital structure $K_{p}$;

$K g$ - the capital gap - uninvested part of the potential capital.

\section{GDP gap $($ niche $)=$ Potential GDP - Real GDP}

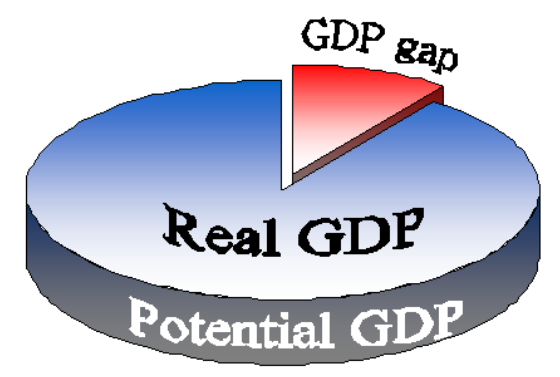

Figure 3. Variable items of the logistic capital model

Source: developed by the author, according to Girdzijauskas, Štreimikienè, Mackevicius, Moskaliova (2009). 
D. Streimikienè, S. Girdzijauskas (2008) note, that the main attention in the created GDP growth model is on the capital accumulation difference or, in other words, the capital gap. Capital gap (niche), by its nature is a very important factor to the progress of economic system, while evaluating and analysing the economic development, but this phenomenon doesn't get enough attention. As already mentioned, in the theory of economic growth four different phases of economic growth cycle occurrence are distinguished - rise, peak, recession and the bottom. S. Girdzijauskas D. Štreimikiene, R. Mackevicius (2009) points out that for the economic bubbles (booms, peaks) characteristic phases are: bubble formation / rapid growth, the price peak / economic boom $\rightarrow$ bubble explotion / price decline $\rightarrow$ stagnation in the sector or depression. The authors also noted that economic cycles and phases of economic bubbles in essence coincide - there is growth, peak, fall and recession phases.

Country's economic growth rate of GDP because of the „bubble“ (boom) effect may greatly increase during the period when capital, creating a GDP, gets close to the maximum amount of capital - an investment capacity, which can be effectively absorbed in the country, i.e. can effectively participate in the creation of GDP, i.e. a small additionaly invested capital to the country's economy, generates high and fundamentally inexplicable returns, which display as the country's economy's GDP growth, so it is stated that in the coutry's economy progresses a bubble (peak) formation process. As the invested capital reaches the limits, economic growth stops, followed by the country's economic bubble burst phase, which manifests itself - by the economic crisis (Girdzijauskas, Štreimikiené, 2009). The economic growth cycle and GNP gap dynamics is shown in Figure 4.

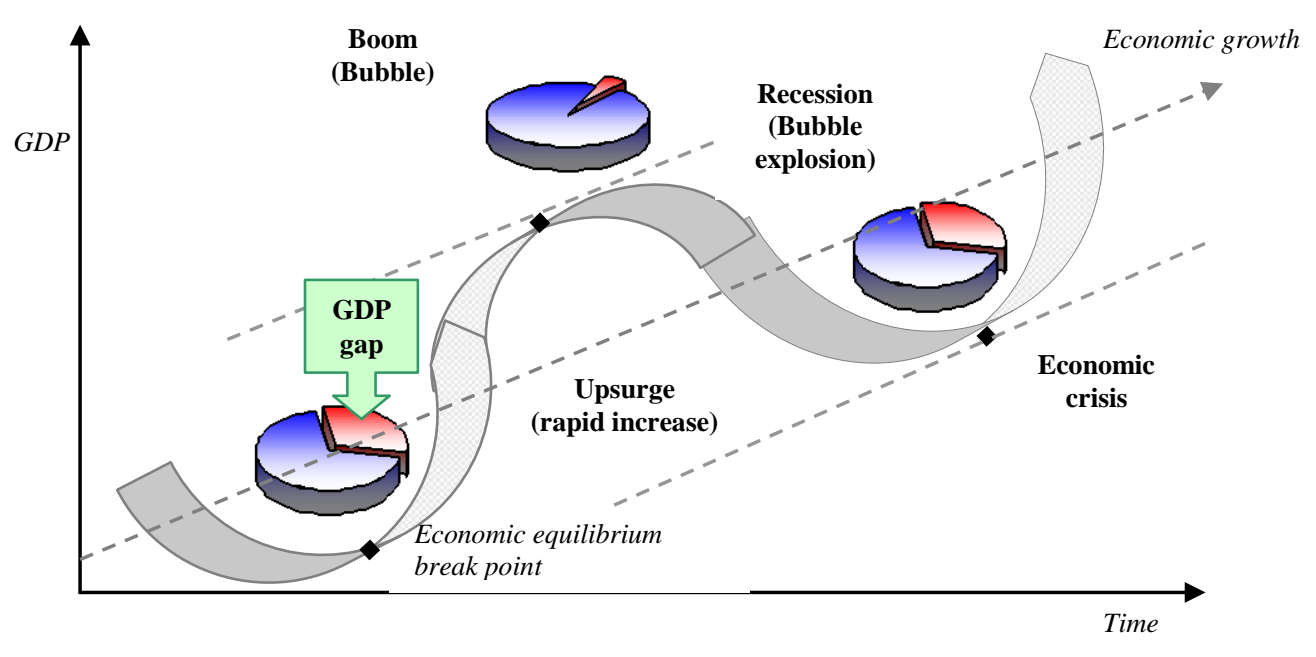

Figure 4. The dynamics of economic growth cycle and GDP gap (niche)

Source: created by the author.

On the basis of fundamental factors set out in the ,logistic capital management theory " - with an increase of money, the demand for products and the profitability - a closed market capacity opportunities shrink, the market saturates to the maximum possible level, therefore investment opportunities reduce (shrink), in other words, investment space gets low, narrows; rising interest rates, growing market prices rapidly increase the inflation rate upsurge - appear potential economic boom (bubble) formation signals. When the economy reaches its limits of investment space, economic growth peak stage - the economic boom phase ends, viewing from the perspective of economic growth cycle at the economic equilibrium occurs economic conjuncture break, from this point economic growth stops and starts to decline, in this case it is stated that the economy has overheated or the inflated bubble exploded and 
moved into the recession phase. Thus, the more investment in the economy, the more the economy is saturated with invested capital - the lower recesses GDP gap part, which means that less of GDP remains for the development and growth. As GDP gap, shown in Figure 4, decreases (residual investment capacity part), significantly increases investment efficiency. In terms of a wide range economy, the shrinkage of the capital niches and the accompanying bubble (peak) is a key factor conditioning the crisis or the end of economic cycle (business).

New innovations are very important for the economic growth and development, they generate economic activity and create thorough preconditions for economic growth. One of the most important innovation factors, enabling the rapid economic growth with a positive impuls - with emergence of new technology, there appears a new closed market, which is filled with great acceleration and great excitement (the second condition for the formation of a bubble) in order to meet the growing needs for the profit, this results in a closed market saturation. Also an important factor extending the boundaries of the market - is the globalization process, which prevents the formation of the economic boom. So until the economy is not filled, it will not overheat and price bubbles will not form, and when it reaches the limits of potential economic market and the market is finally saturated with new technologies - price bubble will form, leading it to burst and the economy will suffer crisis.

Logistic capital management theory clearly shows that the operational success at the economic downturn is determined by free or low constrained ability to dispose of certain resources. Theory accentuates that growth can not be infinite and is characterized by the evaluation of capital limitation, i.e. theory states that there is a finite capacity of capital, representing the maximum amount of capital that can be effectively absorbed in the environment. Thus, the efficiency of the economy - is the country's economic growth rates of GDP, which due to the overheating effect of the economy or the economic bubble can greatly increase at the time when the capital, creating country's GDP is close to potential GDP (capital) limit - the maximum possible amount of capital that the country can effectively absorb, which is effectively involved in the production of GDP.

\section{Conclusions}

After the theoretical review of the scientific literature and analysis of the authors approaches who are dealing with economic growth cyclical fluctuations it was determined that economic growth limitations and the factors influencing it are unvalued.

To the characteristic features of the logistic capital management theory there can be attributed the market capacity and saturation based on the fundamental capital return factors, when economic growth reaches its maximum limit, in the economic growth cycle there forms an economic boom and the following critical period.

Theory states that growth can not be infinite and is characterized by the evaluation of capital limitation, i.e. it is stated that there is a finite capacity of capital, representing the maximum amount of capital that can be effectively absorbed in the environment.

On the basis of claims, the theory proposes ways to expand the capacity of the market, stave off economic overheating and the basic preventive elements of the economic system, names the development of new technologies and identifies the product market extension. Logistic capital management theory can be applied while analyzing the country's economic growth and economic growth cycles.

\section{References}

Besomi, D. (2005), Clément Juglar and the transition from crises theory to business cycle theories. Paper prepared for a conference on the occasion of the centenary of the death 
of Clément Juglar, Paris, 2 December 2005. Prieiga per interneta: http://www.unil.ch/webdav/site/cwp/users/neyguesi/public/D._Besomi_

Blanchard, O. (2007), Macroeconomics. Vilnius: Tyto alba, 696 p.

Burns, A. F., Mitchell, W. (1946), Measuring Business Cycles. Published in 1946 by NBER, (in:) NBER Book Series Studies in Business Cycles http://www.nber.org/books/burn46-1.

Cooley, T. F., Prescott, E. C. (1995), Economic Growth and Business Cycles. Chapter 1. [Interactive] Available at: Economic growth and business cycles

Čiegis, R. (2002), Alternative theories of the sustainable economic development. Monograph. Kaunas. Naujasis lankas press, 2002, 240 p.

Elster, J. (1983), The crisis in economic theory. Review of Nelson and Winter (1982) and J. Roemer (1982), London Review of Books 5 (9): 5-7, http://www.reocities.com/hmelberg/elster/ar83ciet.htm

Fereira, O., C. (1998), Brazilian Economical Growth - 1997 to 2010. [Interactive] Available at: http://ecen.com/eee9/capacume.htm

Freeman, CH. (1982), Innovation and long cycles of ecomonic development. Economics Department, University of Campinas. [Interactive] Available at: 1 INNOVATION AND LONG CYCLES OF ECONOMIC DEVELOPMENT Professor ...pdf

Garber, P. M. (1990), Famous first bubbles. The Journal of Economic Perspectives, Vol. 4, No.2, 35-54 p.

Girdzijauskas, S. (2006), Logistic capital management theory, determined models. Monograph. Vilnius, VU press, 2006, 232 p.

Girdzijauskas, S., Štreimikienè, D. (2008), Logistic Growth Models for Analysis of Stocks Markets Burbles, The 2008 International Conference of Financial Engineering, Lecture Notes in Engineering and Computer Science, p.1166 - 1170.

Girdzijauskas, S., Štreimikinè, D. (2009), Logistic analysis of bussiness cycles, economic bubbles and crises, VU: Kaunas.

Girdzijauskas, S. (2009.12.03), „I am Lithuania“ Lithuanian economical theories. How to control economic crises, VU, KHF.

Girdzijauskas, S., Mackevičius, R. (2009), Capital growth models and logistic capital mangement theory. New approach to the economic crises, Economics \& management, 2009, 14, Kaunas:VU.

Girdzijauskas, S., Streimikienè, D. (2008), Logistic Growth Models for Analysis of Sustainable Growth / Transformations in business and economics. 2008, vol. 7, No. 3 (15), p. $218-235$.

Girdzijauskas, S., Štreimikienè, D., Čepinskis, J., Moskaliova, V. Jurkonytė, E., Mackevičius, R. (2009). Formation of economic bubbles: causes and possible preventions. Technological and economic development of economy Baltic Journal on Sustainability. 15(2): 267-280.

Girdzijauskas, S., Štreimikienè, D., Mackevičius, S. (2009), Logistic Analysis of Ekonomic Fluctuations. Journal of Management. Issue: Volume 14, Number 2/2009.

Martin, A., Ventura, J. (2010), Economic growth with bubbles. NBER. Working Paper 15870. [Interactive] Available at: http://www.nber.org/papers/w15870

Moore, G.H. (1983), Business Cycles, Inflation, and Forecasting. Published in 1983 in http://www.nber.org/books/moor83-1

Moskaliova, V. (2009), Unsustainable economic situations' logistic analysis. PhD thesis. VU, KHF, 2009. 12-18.

Navickas, V., Bagdonaitè, R., Jusčius, V. (2006), Business cycle and small business. Kaunas, University of Technology, 2006, No. 3(48). p. 36-42.

Štreimikienè, D., Ramanauskienè, J. (2005), Structural economics policy and economic growth strategies. Regional development. Kaunas: Technology. 
Портной, М. (2000), Кризисные ичиклы экономики стран Запада и попытки преодолеть. Межд. журнал „Проблемы теории и практики управления“ No.4, http://vasilievaa.narod.ru/ptpu/11_4_00.htm

Тамбовцев, В. (2009), Финансовый кризис и экономическая теория. Журнал „Вопросы экономики“", 2009, No. 1, С. 133-138.

Фомина, А. В. (2005), Цикль Кондратьева в экономике России. Монография, Санкт Петербург, Международный фонд Н. Д. Кондратьева, 146 с. 